\title{
The development of interactive magic card (IMC) based on flash card Review
}

\author{
Abdul Muhith ${ }^{1}$, Ulfa Wulan Agustina ${ }^{2}$, Yuyun Bahtiar ${ }^{3}$, Nurul Afidah ${ }^{4}$ \\ ${ }_{1,2,3}^{3}$ Fakultas Ilmu Pendidikan, Universitas KH. A. WahabHasbullah, Indonesia

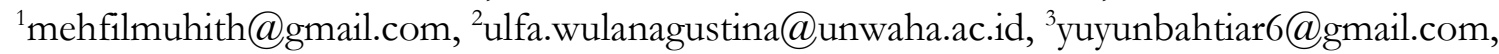 \\ ${ }^{4}$ nurulafidah@unwaha.ac.id \\ *) correspondence: mehfilmuhith@gmail.com
}

\begin{abstract}
This research aimed to develop Interactive Magic Card as a medium that is suited to learning needs. There are 2 objectives in this study; 1) developing Interactive Magic Card as a learning medium; 2) find out the feasibility of the media. This research uses the Research and Development method which was adapted from Borg and Gall. This English learning media is an HTML5-based Flash Card application that was developed to help students in mastering vocabulary and improve their Speaking and Writing skills. The results of this study indicate that; 1) the results of the material expert validation are 89 ; 2) the results of media expert validation are 84 ; 3) main field test results are 91. Based on the results of the study, the researchers concluded that Interactive Magic Cards suitable for use as a medium for learning English.
\end{abstract}

Keywords: Interactive magic card; flash card

\section{INTRODUCTION}

In learning English, vocabulary become one of the elements that must be learned, both mastering reading, listening, listening and writing. As for learning English, some teachers or students find difficulty to mastery English because they do not know the vocabulary. They also have difficulty to speak, write and memorize the vocabulary.

In teaching English educator needs media to deliver material. Media is a media that bring instructional purpose of massages or information of learning. Media is means of expressing massage and information (Sanaky, 2013).Media is one of the tools to facilitate learning and teaching activities. The media is proven effective to help teachers and students to understand the material and to make it fun.

According to Djamara (as cited Mokhammad, 2018), the media in learning has several types, namely visual media, audio media and audio visual media. Media that is often used in learning is visual media or classical media. Visual media is a classic media which can be directly observed.

As a modern media, we often found the multimedia-based media, namely media designed by using technology or computers. The purpose of learning media is making it easier for teachers and students to understand the lesson.

There are some media that is used to master the vocabulary such as picture media, card and paper. Commonly in learning vocabulary the teacher used visual media to teach vocabulary. Visual media is a printing media that contain picture and able to see directly. Visual media often used to teach English language. The visual media commonly used to master vocabulary are Flash cards.

Flash cards are visual learning media that use cards. Commonly flash cards are used as learning media to master vocabulary. The famous flash card media is powerful enough to be used to master vocabulary. Flash card is a card-shaped media where the card contains images, language and how to pronounce it, make it easier for students to memorize and understand English vocabulary (Fitriani\&Nulanda, 2017). 
Muhith, A., Agustina, U.W., Bahtiar, Y., Afidah, N.

Along with the advancement of technological development, spurring every educator and researcher to develop a learning media with the aim of making it is easier and more effective in its use such as flash cards. In general, flash cards only use a media card that contains images, language and how to pronounce it. With the development of technology, educators and researchers try to develop flash card media into learning media that is more practical, easy and effective. From there educators and researchers developed flash card learning media that were originally based classically into modern flash cards or often referred to as multimedia-based flash card media.

Interactive Magic Card (IMC) is one of the multimedia-based flash card learning media. Interactive Magic Card (IMC) is specifically designed to solve problems in English learning especially in vocabulary learning in English learning. IMC is intentionally designed using multimedia with the aim that educators and students are easier, more practical, and effective in understanding and mastering English, especially in vocabulary learning.

\section{METHODS}

This research uses Research and Development method developed by Borg and Gall. The following descriptions are:

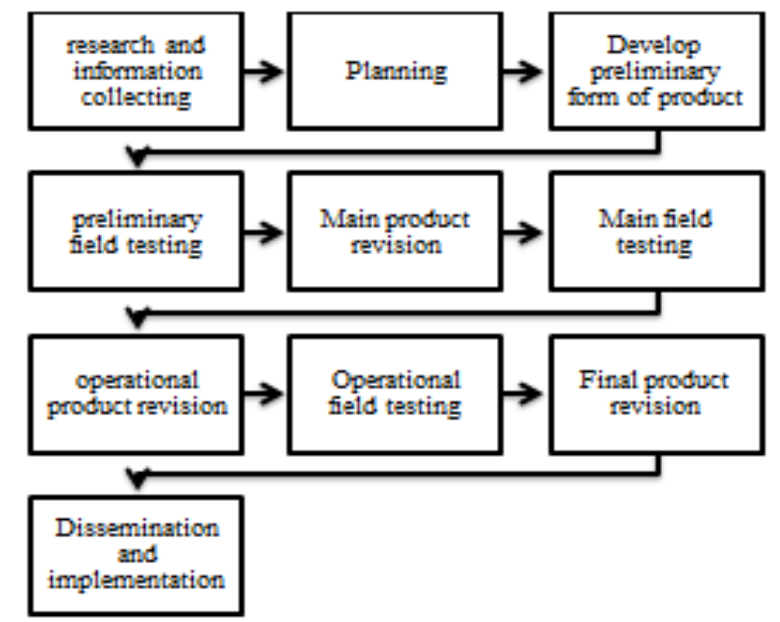

Figure 1. The procedure of research and development (Borg \& Gall)

\section{Research and Information Collecting Data}

The researcher makes like a pre-research and gathering suitable data that will support the research and give estimation for the acceptable media application according the data.

\section{Planning the Research}

The researcher makes a plan for conduct the research. Include the theme, materials for the media, supporting tools, previous study and so on.

\section{Develop Preliminary Form of Product}

This is the main process, there is to make new product. The researcher make it based on the previous product with additional or disappear some items depend on the goal.

\section{Preliminary field testing}

The researcher do the first trial and judged by the expert to identify how the product running well. It will be conducted to the expert and for the participant (user learner). They will fulfill the questionnaire. With the testing, the author will identify some revisions for the product to make it more perfect.

\section{Main product revision}

The product revision was based on suggestion and addition by preliminary field testing. Hoped from the next testing, the result of product will increase than before. Data for this research consist of two types and will be collaborated for getting the specific and maximal result.

\section{Main field testing}


This field testing with renewable media is getting previous revision. In this step, there will look for the learner response according to the questionnaire.

\section{Final product revision}

This is follow up after the previous step before the product will be published and disseminated

\section{RESULTS AND DISCUSSION}

This chapter discusses the result of development and answers the objectives of the research. According to Sugiono (as cited in Rima, 2016) Research and Development is a Research method used to make a product and test the effectiveness of product.This chapter is divided into four parts. The first is the result of developing product. The second is the result of expert validation and revision. The third is the result of try out, and the fourth is the final product.

Developing product

1. The researcher concluded the result of observation and interviews as follow:

2. The teacher used demonstration method to teach English material, the teacher only explains and then the students do the exercise on the students' worksheet.

3. The students have difficulty to speak the vocabulary correctly. This indicated when the researcher asked the students to pronounce a word.

4. The students have difficulty to memorize the vocabulary quickly. This indicated when the researcher asked the students about some vocabularies that is memorized.

5. The students have problems in writing words. This indicated when the researcher asks the students to write some vocabularies correctly.

Based on the observation and interview, the researcher concluded that the students have problem in understanding the meaning of some vocabularies.

\section{Expert Validation}

Table 1. Media validation

\begin{tabular}{|c|l|c|c|c|c|}
\hline No & \multicolumn{1}{|c|}{ Aspect } & Item & $\begin{array}{c}\text { Obtained } \\
\text { Score }\end{array}$ & $\begin{array}{c}\text { Maximum } \\
\text { Score }\end{array}$ & Percentage \\
\hline 1. & Design & 5 & 9 & 10 & $90 \%$ \\
\hline 2. & $\begin{array}{l}\text { Text typogra } \\
\text { phy }\end{array}$ & 5 & 13 & 15 & $87 \%$ \\
\hline 3. & Image & 5 & 23 & 25 & $92 \%$ \\
\hline 4. & Audio & 5 & 9 & 10 & $90 \%$ \\
\hline 5. & Packing & 5 & 9 & 10 & $90 \%$ \\
\hline 6. & Utilizing & 5 & 17 & 20 & $85 \%$ \\
\hline 7. & Navigation & 5 & 9 & 10 & $90 \%$ \\
\hline & Total & 30 & 89 & 100 & $89 \%$ \\
\hline
\end{tabular}

Based on the table above, the score showed that $89>89 \%$ it means that the result of Interactive Magic Card (IMC) based on media validation is "Good" classification.

Table 2. Mastery Validation

\begin{tabular}{|l|l|c|c|c|c|}
\hline No & Aspect & Item & $\begin{array}{c}\text { Obtained } \\
\text { Score }\end{array}$ & $\begin{array}{c}\text { Maximum } \\
\text { Score }\end{array}$ & Percentage \\
\hline 1. & Curriculum & 5 & 4 & 5 & $80 \%$ \\
\hline 2. & User & 5 & 19 & 20 & $95 \%$ \\
\hline 3. & Opening & 5 & 9 & 10 & $90 \%$ \\
\hline 4. & Content & 5 & 39 & 45 & $87 \%$ \\
\hline 5. & Closing & 5 & 7 & 10 & $70 \%$ \\
\hline & Total & 25 & 78 & 90 & $84 \%$ \\
\hline
\end{tabular}


Muhith, A., Agustina, U.W., Bahtiar, Y., Afidah, N.

Based on the table above, the score showed that $70>84 \%$ it means that the result of Interactive Magic Card (IMC) based on material validation is "Good" classification. The expert validator added the suggestion as follow:

1. The product is less of intruction button,

2. The material is static,

3. There is no benchmark of success

\section{The result of main field testing}

On this part, the researcher did the main field testing in Al-Muhibbin Islamic Boarding School Tambakberas, Jombang. There are 10 students who fill out the questionnaires. The ability of students consists of different level; these are low, middle and high level. They were chosen by the result of observation, need analysis and discussions to the teacher. On the main field testing, the researcher used ten computers and a projector tools to support the implementation of media. These activities are done in the class.

Table 3. The result of questionnaire analysis

\begin{tabular}{|c|c|c|}
\hline No & Students & Score \\
\hline 1 & A & 95 \\
\hline 2 & B & 88 \\
\hline 3 & C & 90 \\
\hline 4 & D & 92 \\
\hline 5 & E & 92 \\
\hline 6 & F & 90 \\
\hline 7 & G & 93 \\
\hline 8 & I & 93 \\
\hline 9 & J & 93 \\
\hline 10 & K & 917 \\
\hline & TOTAL SCORE & 91,7 \\
\hline
\end{tabular}

Based on the above, the main field testing get score 91,7. It means that the media of IMC in a very good category. Based on the score, the media of IMC is no needed revision.

\section{Final Product}
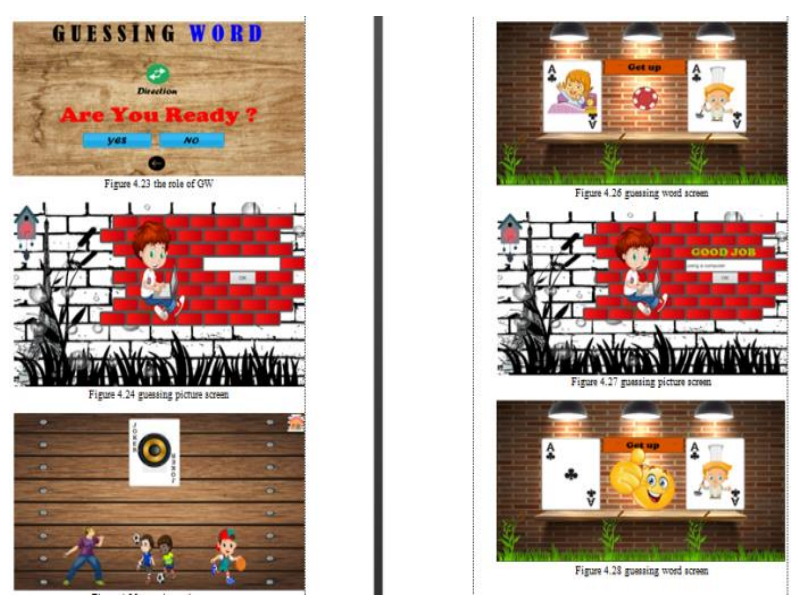


\section{CONCLUSION}

Based on the result of research and discussion, the researcher concluded that IMC (Interactive Magic Card) media designed by researcher is easy to use in English learning. The feasibility based on: The result of media validation is 85 score in good category, the result of material validation on the first validation is 60 score in fair category and on the second validation is 85 in a good category, and the result of user validation in preliminary field study is 88,16 score and get 90,30 score in field study.

\section{REFERENCES}

Anisa. 2018. Designing King Al post as English Teaching Media for Beginner Students. Skripsi tidak diterbitkan. Jombang: Fakultas Ilmu Pendidikan Universitas KH. A. Wahab Hasbullah.

Aprianto.(2015)

Media

Pembelajaran,

(Online). (http://dikyaprianto0.blogspot.com/2015/01/media-pembelajaran.html?m=1, diakses8 januari 2015).

Asyari\& Silvia.(2016). Pengembangan Media Pembelajaran Berupa Bulletin Dalam Bentuk Buku Saku untuk Pembeljaran IPA Terpadu. Jurnal Ilmiah Pendidikan Fisika, (Online). Vol. 5, No. 1, (http://ejournal.radenintan.ac.id/index.php/al-biruni/article/view/100, diakses 5 april 2016).

Fitriyani\&Nulanda.(2017). Efectifitas Media Flash Card dalam Meningkatkan Kosa Kata Bahasa Inggris. Jurnal ilmiah psikologi, (Online). Vol. 4, No. 2, (https://journal.uinsgdac.id/index/php/psy/article/view/1744, diakses 2017).

Frida.(2009). Function And Benefits Of Learning Media, (Online). (https://www.google.com/amp/s/educationlearning.wordpress.com/2009/01/16/function -and-benefits-of-learning-media/amp/diakses 16 januari 2009).

Huda. (2018). PengertiandanDefinisi Media Pembelajaran, (Online).(http://fatkhan.web.id/pengertian-dan-definisi-media-pembelajaran/diakses 23 januari 2018).

Madasari.(2012). Pengembangan media pembelajaran flash card berbasis computer pada standar kompetensi menjelaskan dasar-dasar sinyal video di SMK NEGERI 1 SIDOARJO. Jurnal pendidikan tekhnik electro, (Online).Vol. 1, No. 2, (https://jurnalmahasiswa.unesa.ac.id/index/php/jurnal-pendidikan-electro/issue/view/92, diakses 2012).

Mokhammad.(2018). Jenis media pembelajaran, (Online).(https://www.haruspintar.com/jenis-jenismedia-pembeljaran/diakses 5 agustus 2018).

Muhson.(2010). Pengembangan media pembelajaran berbasis tekhnologi informasi. Jurnal pendidikan akuntansi Indonesia, (Online).Vol. 8, No. 2, (https://journal.uny.ac.id/index.php/jpakun/article/view/949, diakses 1 desember 2016).

Natsya.(2015). Media pembelajaran berbasis multimedia, (Online). (http://ekanatasya999.com/2015/06/media-pembelajaran-berbasis-

multimedia_7.html?m=/diakses 7juni2015).

Rima.(2016). Penelitian dan pengembangan research, (Online). (https:/ / rimatrian.blogspot.com/2016/11/penelitian-dan-pengembanganreseacrh.html?m=1, diaksesnovember 2016)

Sahaja.(2014). Pengertian media pembelajaran, (Online). (https://irwansahaja.blogspot.com/2014/08/pengertian-media-pembelajaran.html?m=1, diakses 16 maret 2012).

Sanaky.(2013). Media pembelajaran interaktif-inovatif. Yogyakarta: KAUKABA DIPANTARA. Sofianti.(2016). Pengumpulan data kuisioner atau angket, (Online). (https://www.googele.com/amp/s/sofianti.wordpress.com/2016/05/15/metodepengumpulan-data-kuisioner-atau-angket/amp/diakses 15 mei 2016). 